\title{
Nymphaea lotus L. and Nymphaea micrantha Guill. et Perr Seeds as Cereal Substitute in the Delta of Senegal River
}

\author{
Fatou Kine Gueye1, Nicolas Cyrille Ayessou2², Mame Samba Mbaye1, Michel Bakar Diop, \\ Mady Cissé2, Kandioura Noba ${ }^{1}$ \\ ${ }^{1}$ Laboratoire de Botanique-Biodiversité, Biologie Végétale, University Cheikh Anta Diop, Dakar, Senegal \\ ${ }^{2}$ Laboratoire d'Electrochimie et des Procédés Membranaires/Centre d'Etudes sur la Sécurité Alimentaire et les Molécules \\ Fonctionnelles-Ecole Supérieure Polytechnique, University Cheikh Anta Diop, Dakar, Senegal \\ ${ }^{3}$ Unité de formation et de Recherche des Sciences Agronomiques, de l'Aquaculture et des Technologies Alimentaires University \\ Gaston Berger, Saint-Louis, Senegal \\ Email: kinelouis@hotmail.fr, ${ }^{*}$ nicolas.ayessou@ucad.edu.sn, *nayessou@yahoo.fr, msmbaye@yahoo.fr, \\ michel-bakar.diop@ugb.edu.sn,mady.cisse@ucad.edu.sn,kandioura.noba@ucad.edu.sn
}

How to cite this paper: Gueye, F.K. Ayessou, N.C., Mbaye, M.S., Diop, M.B., Cissé, M. and Noba, K. (2020) Nymphaea lotus L. and Nymphaea micrantha Guill. et Perr Seeds as Cereal Substitute in the Delta of Senegal River. Food and Nutrition Sciences, 11, 375-384. https://doi.org/10.4236/fns.2020.115027

Received: April 10, 2020

Accepted: May 10, 2020

Published: May 13, 2020

Copyright $\odot 2020$ by author(s) and Scientific Research Publishing Inc. This work is licensed under the Creative Commons Attribution International License (CC BY 4.0).

http://creativecommons.org/licenses/by/4.0/

\section{(c) (i) Open Access}

\begin{abstract}
Studies conducted in the delta and lower valley of Senegal river have demonstrated through ethnobotanical surveys, the importance of Nymphaea lotus L. and Nymphaea micrantha Guill. et Perr in the diet and in the pharmacopoeia. The seeds are used with good appreciation by the indigenous population as a welding food. But studies addressing their biochemical and nutritional aspects are still very rare in the literature. This study was initiated in order to fill this gap and allow a better appreciation of the nutritional and energetic potentialities of these seeds. For this purpose, seeds were collected in effluent from the Senegal River, dried in the shade and put into three different batches: a batch of red seeds of $N$. lotus, a batch of Black seeds of $N$. lotus and a batch of seeds of $N$. micrantha. The biochemical analyses gave their moisture content $(9.17 \% \pm 0.2 \%$ to $13.36 \% \pm 3.46 \%)$, aw $(0.46 \%$ to $0.71 \%)$, protein $(7.90 \% \pm 1.25 \%$ to $8.24 \% \pm 0.5 \%)$, lipid $(2.32 \% \pm 0.45 \%$ to $4.29 \% \pm 1.0 \%)$, carbohydrate $(74.49 \% \pm 0.9 \%$ and $77.66 \% \pm 1.65 \%)$, mineral matter $(1.77 \% \pm 0.06 \%$ to $2.55 \% \pm 0.08 \%)$. All three types of seeds have high levels of potassium $(481.10 \% \pm 17.62 \%$ to $770.81 \% \pm 42.33 \%)$, magnesium $(312.71 \% \pm 14.08 \%$ to $518.67 \% \pm 15.23 \%)$ and calcium $(188.81 \% \pm 8.52 \%$ to $296.52 \% \pm 16 \%$. Their energy values $(350.54 \pm 15.21 \mathrm{kcal} / 100 \mathrm{~g}$ to $375.7 \pm 3.48$ $\mathrm{Kcal} / 100 \mathrm{~g}$ ), are closed to other cereals consumed in the human diet in Senegal. Therefore, these seeds offer the opportunity to diversify the diet in the delta and lower valley of the Senegal River.
\end{abstract}




\section{Keywords}

Nymphaea Seeds, Nutritional Value, Senegal

\section{Introduction}

Food security and safety are major challenges in countries around the world, currently facing climate hazards and population growth. All over the word, 821 million people or one person out of nine, are suffering from hunger in 2017 [1]. This remains a serious problem in Africa where the population was above exceeded 1 billion in 2009 and continues to grow [2]. However facing to these challenges there is growing interest to consider the called neglected and under-used species. In fact, they have considerable potential to ensure food security and cover the population's health, care needs and contribute to the poverty reduction effort [3] [4]. Most of the plant species can provide food and are used to complete nutrients [5]. Otherwise, they are used for traditional medicines [6], such as Dioscorea rotundata [7], Maerua pseudopetalosa [8] and Cyperus esculentus [9]. Wild fruits of Nymphaea lotus and Nymphaea micrantha also fall into this group. They are aquatic species that are abundant in the freshwater of the Senegal River valley. Attention has so far focused on their ornamental character through their domestication [10]. Recently, the therapeutic properties of N. Iotus's leaves have been demonstrated in the treatment of breast cancer [11], in the regulation of blood pressure and the restoration of erectile function [12]. Rhizomes of Nymphaea are also used for tanning [13]. In terms of food, almost all part of the species are useful (leaves, peduncles, flowers, stems, rhizomes and seeds) of the genus Nymphaea are edible such as in Northern Ghana [14], in Equateur Province-R. [15]. All these studies have shown the potential that can still be derived from these species. In Senegal, seeds of N. lotus and N. micrantha have been used to supplement diet in time of food shortage [16]. They have numerous socio economic uses in the region of Senegal River valley [16] such as ornamental characters [10], sold for therapeutic properties [11] [12], and for tanning [13]. Despite the importance of those species there is a dearth of information on their biochemical and nutritional components. This study was initiated in order to fill this gap and to allow a better appreciation of the nutritional potentialities of Nymphaea's seeds.

\section{Material and Methods}

\subsection{Biological Materials}

Three batches of water lily seed were established from three species. N. lotus with black seeds (batch 1); N. lotus with red seeds (batch 2) and N. micrantha (red seeds (Figure 1). Each N. lotus batch consist of 3 samples collected from three effluents of the Senegal River at the villages of Ndiaye $\left(16^{\circ} 12^{\prime} 7^{\prime \prime} \mathrm{W}\right.$; $\left.16^{\circ} 15^{\prime} 55^{\prime \prime} \mathrm{N}\right)$, Mboudom $\left(16^{\circ} 03^{\prime} 30^{\prime \prime} \mathrm{W} ; 16^{\circ} 25^{\prime} 45^{\prime \prime} \mathrm{N}\right)$ and Ndiandane $\left(14^{\circ} 59^{\prime} 12^{\prime \prime} \mathrm{W}\right.$; 

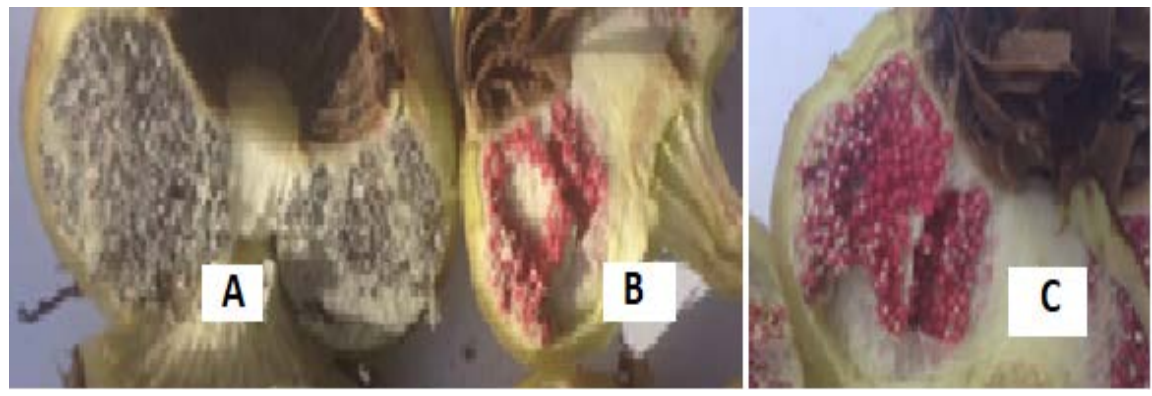

Figure 1. $\mathrm{A}=N$. lotus with Black seeds; $\mathrm{B}=N$. lotus with Red seeds; $\mathrm{C}=N$. micrantha with red Seeds.

$16^{\circ} 35^{\prime} 06^{\prime \prime N}$ ). The third batch of N. micrantha seeds (Lot 3) is made of two samples from two effluents in Saint-Louis $\left(16^{\circ} 24^{\prime} 21^{\prime \prime} \mathrm{W} ; 16^{\circ} 03^{\prime} 24^{\prime \prime} \mathrm{N}\right)$ and Ross-bethio $\left(16^{\circ} 07^{\prime} 05^{\prime \prime} \mathrm{W} ; 16^{\circ} 17^{\prime} 59^{\prime \prime} \mathrm{N}\right)$. The samples are dried in the shade at room temperature $\left(30^{\circ} \mathrm{C}\right)$ for 48 hours and sent to the laboratory for characterization.

\subsection{Methods}

Caracterization of Nympea's seeds consist to determine several parameters. The moisture content of the seeds was determined after dehydration at $105^{\circ} \mathrm{C}$ according to the official method AFNOR NF V 03-921. The nitrogen component was determined by Kjeldhal's method according to NF 03-050 [17] and proteins were calculated using 5.7 as coefficient. The total minerals were determined after 4 hours incineration at $550{ }^{\circ} \mathrm{C}$ according to V76-101 method [17]. After incineration the ashes were collected in a mixture of hydrochloric and nitric acids. The content of potassium, calcium, magnesium and sodium were evaluated by determination with an atomic absorption spectrometer according to the guidelines of the AFNOR standard NF V76-122 [17]. The lipid determination was carried out by weighing the fats after Soxhlet extraction with diethyl ether according to the method NF V 03-905 [17]. The carbohydrate content was evaluated by calculation, using the average between the content of water, ash and other organic matter of (protein or nitrogen component and lipid content). The energy value is calculated according to Atwater formula [18].

\subsection{Statistical Analyzes}

The one-way analysis of variance (ANOVA) test was used in this research combined with the STATISTICA 7.1 software at 5\% level of significance. Through this statistical analysis samples are compared according to each parameter. Statistical differences with a probability value less than $0.05(\mathrm{P}<0.05)$ are considered significant.

\section{Results and Discussion}

This study has determined the major biochemical composition of $N$. lotus and $N$. micrantha seeds and assessed their energy and nutritional intake. This preliminary work is one of nutritional interest following previous studies in the 
same region by Gueye et al. (2019) [16]. These two species are prized and edible in the delta and lower Senegal River's valley. Their fruits are globular and filled with seeds. They can undergo stages of sun drying and grinding into flour that is often consumed in main dishes [16]. Water lily seeds are also consumed in northern Ghana [14], Equator Province of Congo [15], China, East India and the Philippine Islands [10]. Floury bulbs reminiscent of potatoes; they are roasted, boiled or cooked under ashes and can be dried and reduced to flour, According to Betti and Mebere Yemefa (2011) [19], in the far north of Cameroon, the flowers and stems are also consumed as appetizers. All these uses showed that species of this genus are potentially valuable for human consumption.

\subsection{Moisture and Water Activity}

Water activity values varied between $0.46 \%$ and $0.71 \%$ and the lowest is noted in $N$. lotus black seeds (Table 1). Water activity has values below $0.75 \%$ and is in the considered in food chemistry to stabilize food [20]. Table 1 shows a significant difference with respect to the water activity $(\mathrm{Aw})$ from different seeds analysed (P-value < 0.05). Water activity is an important parameter in food that can prevent the risk to spoil the food. The biochemical and microbiological stability of food could be compromised if the values are too high, as this would reduce the shelf life [21] [22]. In general, $N$. lotus and $N$. micrantha seeds have Aw's values that guarantee their good stability. The low values are correlated with those of the water content. To characterize the samples, the moisture content is generally low (not exceeding 10\%), indicating good seed storage. Moisture values obtained is between $9.17 \% \pm 0.2 \%$ and $13.36 \% \pm 3.46 \%$ (Table 1). Comparison of the averages shows that the moisture contents are statistically identical (at the 0.05 threshold) between the three types of seeds. Nevertheless, red N. lotus seeds have higher moisture contents than black seeds $(13.36 \% \pm 3.46 \%$ and $9.66 \% \pm 0.61 \%$ respectively). These values are close to those of peanuts, beans, and pigeon peas, which average $10 \%$ [23]. However, they are higher than those of $N$. lotus seeds reported in Nigeria by Mohammed et al., 2013 [24] (4.18 \pm $0.176)$ and Wasagu et al., 2015 [25] (6.00\% $\pm 0.45 \%)$. This difference could be

Table 1. Proximate components and energy value of Nymphaea's seeds.

\begin{tabular}{ccccc}
\hline & $\begin{array}{c}\text { Seeds } \\
\text { of } N \text {. micrantha }\end{array}$ & $\begin{array}{c}\text { Black seeds } \\
\text { of } N \text {. lotus }\end{array}$ & $\begin{array}{c}\text { Red seeds } \\
\text { of } N \text {. lotus }\end{array}$ & P-values \\
\hline Moisture (\%) & $9.17 \pm 0.02 \mathrm{a}$ & $9.66 \pm 0.61 \mathrm{a}$ & $13.36 \pm 3.46 \mathrm{a}$ & 0.1512398 \\
Aw (\%) & $0.46 \pm 0.06 \mathrm{a}$ & $0.45 \pm 0.05 \mathrm{~b}$ & $0.71 \pm 0.01 \mathrm{c}$ & 0.04231344 \\
Protein (\% DM) & $7.90 \pm 1.25 \mathrm{a}$ & $8.24 \pm 0.50 \mathrm{a}$ & $7.93 \pm 2.29 \mathrm{a}$ & 0.4169 \\
Lipids (\% DM) & $2.71 \pm 0.50 \mathrm{a}$ & $4.29 \pm 0.10 \mathrm{a}$ & $2.32 \pm 0.45 \mathrm{a}$ & 0.4389 \\
Glucid (\% DM) & $77.66 \pm 1.65 \mathrm{a}$ & $76.04 \pm 1.36 \mathrm{a}$ & $74.49 \pm 0.90 \mathrm{a}$ & 0.893 \\
Energy (Kcal/100g) & $366.65 \pm 2.97 \mathrm{a}$ & $375.7 \pm 3.48 \mathrm{ab}$ & $350.54 \pm 15.21 \mathrm{~b}$ & 0.0622 \\
\hline
\end{tabular}

DM: dry matter; $a, b, c$ : In the same row, means followed by a different letter are significantly different at the $\mathrm{P}<5 \%$ threshold (Newman and Keuls' method). 
due to local thermal and hygrometric conditions. The moisture content from seeds is a determining factor in the prevention of insect infestations as dried grains with a moisture content below $12 \%$ inhibit the development of most insect pest species [23]. Several previous works highlight the importance of moisture as it has an impact on processing conditions and product stability [26].

\subsection{Proximate Components}

The protein content (Table 1) is between $7.90 \% \pm 1.25 \%$ and $8.24 \% \pm 0.5 \% \mathrm{DM}$. The results have showed that $N$. micrantha seeds and $N$. lotus seeds have significantly identical protein contents ( $\mathrm{P}$-value $>0.05)$. The highest level was observed in black $N$. lotus seeds $(8.24 \pm 0.5)$. The protein level obtained in the seeds of Nymphaea. spp (above 7.5\%) is close to the values of Vigna unguiculata variety Katiola $(10.193 \pm 0.075)$ [27]. However, they are much higher than the values reported by Musa et al. (2012) [28] (3.09\% $\pm 0.08 \%)$ and Wasagu et al. (2015) [25] (1.04\% $\pm 0.17 \%)$ for $N$. lotus seeds.

The determination of the lipid level allows the evaluation of the energy reserve of Nymphaea seeds. The range varies from $2.32 \% \pm 0.45 \%$ to $4.29 \% \pm 1.0 \%$ with a highest content in black $N$. lotus seeds $(4.29 \% \pm 1.0 \%)$ and lowest in red $N$. lotus seeds $(2.32 \pm 0.45)$. N. micrantha had a content of $2.71 \% \pm 0.5 \%$. Lipid contents did not vary according to the types of seeds analysed. However, they are comparable to those reported for Pennisetum glaucum (6.0 \pm 1.5$)$ [29], Zea mays (6.1 \pm 2.3$)$, Sorghum bicolor ( $4.5 \pm 0.9)$, Digitaria exilis $(3.25 \% \pm 3.9)$ [30] and Cicer arietinum (6.0 g/100) [31]. However, they are higher than those of pulses such as Pisum sativum (1.2 g/100), Phaseolus vulgaris $(0.9 \mathrm{~g} / 100)$ and Lens culi$\operatorname{naris}(1.1 \mathrm{~g} / 100)$ [31].

Carbohydrate levels in Nymphaea sp. seeds range from $74.49 \% \pm 0.9 \%$ to $77.66 \% \pm 1.65 \% \mathrm{DM}$ (Table 1). No significant differences were observed following a statistical comparison of the means. The species $N$. micrantha had the highest seed content $(77.66 \% \pm 1.65 \% \mathrm{DM})$ while the black and red seeds of $N$. lotus contain less with $76.04 \% \pm 1.36 \%$ and $74.49 \% \pm 0.9 \%$ respectively. Stored in the form of starch in cereals, carbohydrates are assimilated to natural laxatives which can facilitate digestion and thus constitute a source of energy used in a primordial way by the organism [32]. Moreover, the carbohydrate contents found in this study are similar to those reported by Wasagu et al. (2015) [25] in leaves $(71.83 \% \pm 1.63 \%)$, roots $(61.31 \% \pm 1.86 \%)$ and seeds of $N$. lotus $(80.96 \pm$ 0.37). They are also comparable to those of Sorghum bicolor $(74.4 \pm 2.0)$ [29] and Digitaria exilis $(79.05 \% \pm 23.9 \%)$ [31]. This high quantity in Nymphaea seeds could be an asset for their valorization in the manufacture of marketable by-products such as starch, glucose and even alcohol.

Regarding the energy intake of these seeds in human food, black $N$. lotus seeds have the best values $(375.7 \pm 3.48 \mathrm{Kcal} / 100 \mathrm{~g}) . N$. micrantha seeds and red $N$. lotus seeds have significantly different values and respectively $366.65 \pm 2.97$ $\mathrm{kcal} / 100 \mathrm{~g}$ and $350.54 \pm 15.21 \mathrm{kcal} / 100 \mathrm{~g}$ (Table 1). These values are close to those 
reported by Musa et al., 2012 [28] for $N$. lotus seeds ( $399.35 \mathrm{kcal} / 100 \mathrm{~g})$. They are also close to those others species commonly consumed in the human diet (Table 2). This shows that $N$. lotus and $N$. micrantha seeds can contribute to dietary diversification and provide a very good source of energy.

\subsection{The Mineral Matter of Nymphaea Seeds}

The total mineral content was $2.55 \% \pm 0.08 \%$ for $N$. micrantha, $1.77 \% \pm 0.06 \%$ for black $N$. lotus seeds and $1.89 \% \pm 11 \%$ for red $N$. lotus seeds, with a significant difference between $N$. micrantha and red $N$. lotus seeds (Table 3). The black $N$. lotus seeds have a content close to both types of seeds. The major mineral content of the different Nymphaea seeds is presented in Table 3. The results for sodium showed no significant difference $(\mathrm{P}>0.05)$ between the three types of seeds and are low (11.0 mg/100g in average). However, for potassium, calcium and magnesium, there was a significant difference between $N$. micrantha seeds and red and black $N$. lotus seeds. $N$. micrantha seeds are the ones containing more minerals with $770.81 \pm 42.33$ for potassium, $518.67 \pm 15.23$ for magnesium, $296.52 \pm 16.3$ for calcium and $13.52 \pm 1.14 \mathrm{mg} / 100 \mathrm{~g}$ for sodium. Moreover, the three types of seeds analysed showed a higher potassium content (ranging from 454 to $770.81 \mathrm{mg} / 100 \mathrm{~g}$ ), similar to berries and exotic fruits (e.g. strawberry, blackcurrant, grape, African akee, orange, avocado, banana, date, fig) which

Table 2. Comparison between Nymphaea seeds analysed in this study and others seeds reported [33].

\begin{tabular}{|c|c|c|c|c|c|c|c|c|c|c|c|c|}
\hline $\begin{array}{l}\text { Proximate }(\mathrm{g} / 100 \mathrm{~g} \\
\text { matière } \mathrm{DM})\end{array}$ & 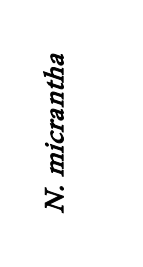 & 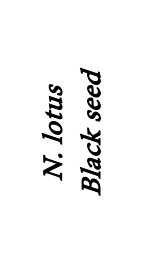 & 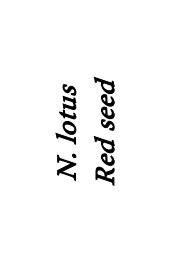 & 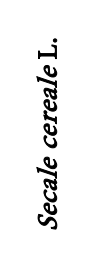 & 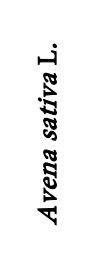 & 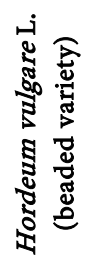 & 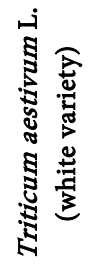 & 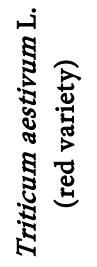 & 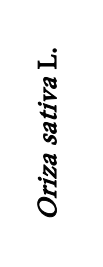 & 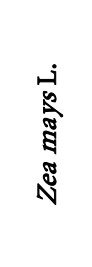 & 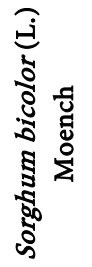 & 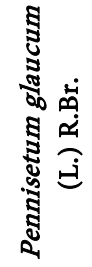 \\
\hline Protein & 7.9 & 8.24 & 7.93 & 10.34 & 16.89 & 9.91 & 11.31 & 12.61 & 7.94 & 9.42 & 11.3 & 11.02 \\
\hline Total lipid & 2.71 & 4.29 & 2.32 & 1.63 & 6.9 & 1.16 & 1.71 & 1.54 & 2.92 & 4.74 & 3.3 & 4.22 \\
\hline Glucid & 77.66 & 76.04 & 74.49 & 75.86 & 66.27 & 77.72 & 75.9 & 71.18 & 77.24 & 74.26 & 74.63 & 72.85 \\
\hline Energy (Kcal/100g) & $66.65 \pm 2.97$ & $375.7 \pm 3.4$ & $350.54 \pm 15.2$ & 337.79 & 389.47 & 352.39 & 342.34 & 327.27 & 370.33 & 365.31 & 339.23 & 378.46 \\
\hline
\end{tabular}

Table 3. Mineral content of Nymphaea's seeds.

\begin{tabular}{cccccc}
\hline \multirow{2}{*}{ Element } & Unit & N. micrantha & N. lotus & N. lotus & \multirow{2}{*}{ P-values } \\
\cline { 4 - 5 } & & & $($ black seed $)$ & (red seed) & \\
\hline Ash & $(\%)$ & $2.55 \pm 0.08 \mathrm{a}$ & $1.77 \pm 0.06 \mathrm{ab}$ & $1.89 \pm 11 \mathrm{~b}$ & 0.01656 \\
$\mathrm{~K}$ & & $770.81 \pm 42.33 \mathrm{a}$ & $481.10 \pm 17.62 \mathrm{~b}$ & $454.32 \pm 42.67 \mathrm{c}$ & 0.01073 \\
$\mathrm{Ca}$ & & $296.52 \pm 16.3 \mathrm{a}$ & $188.81 \pm 8.52 \mathrm{~b}$ & $193.06 \pm 13.29 \mathrm{c}$ & 0.007266 \\
$\mathrm{Mg}$ & $(\mathrm{mg} / 100 \mathrm{~g})$ & $518.67 \pm 15.23 \mathrm{a}$ & $312.71 \pm 14.08 \mathrm{~b}$ & $317.48 \pm 21.62 \mathrm{c}$ & 0.002905 \\
$\mathrm{Na}$ & & $13.52 \pm 1.14 \mathrm{a}$ & $11.55 \pm 2.21 \mathrm{a}$ & $8.99 \pm 6.83 \mathrm{a}$ & 0.6065307 \\
\hline
\end{tabular}


contain 59 to $782 \mathrm{mg} / 100 \mathrm{~g}$ dry matter [34]. However, the sodium content is found to be the lowest among the dosed minerals. This remark is confirmed by Musa et al., 2012 [28]. In general, apart from sodium, all other minerals from the three types of seeds (potassium, calcium, magnesium) have high values that are above $180 \mathrm{mg}-100 \mathrm{~g}-1$ dry matter. This is an indication that seeds of Nymphaea spp. would probably be important for the prevention of certain diseases. Indeed, these nutrients have a positive impact on the maintenance and regulation of blood pressure [35] which remains one of the biggest problems of our populations.

This study has shown that Nymphaea spp. seeds are seeds are comparable to cereals that are important in the diets of populations all over the word. This justifies their use in the past as a substitute for rice and millet during the dearth period. In addition, Nymphaea spp. seeds offer an opportunity for rural women to improve their income by adding value to them and marketing them on a larger scale.

\section{Conclusion}

This study is a contributory approach in the knowledge of neglected and under-used species in order to better understanding of their nutritional input. The dietary importance of $N$. lotus and N. micrantha seeds was demonstrated to be a good manner to diversify the diet. However, regarding valorization, some complementary investigations such as secondary metabolites, fatty acids profile, should improve a better knowledge of these seeds.

\section{Acknowledgements}

The publication fee of this paper was possible thanks to the support of the European DAfrAli research project.

\section{Conflicts of Interest}

The authors declare no conflicts of interest regarding the publication of this paper.

\section{References}

[1] Food and Agriculture Organisation (2018) l'état de la sécurité alimentaire et de la nutrition dans le monde: renforcer la résilience face aux changements climatiques pour la sécurité alimentaire et la nutrition. FAO, FIDA, OMS, PAM, UNICEF.

[2] World Bank (2011) The Little Data Book on Africa. Washington, D.C.

[3] Mayes, S., Massawe, F.J., Alderson P.G., Roberts, J.A., Azam-Ali, S.N. and Hermann, M. (2011) The Potential for Underutilized Crops to Improve Security of Food Production. Experimental Botany, 63, 1-5. https://doi.org/10.1093/jxb/err396

[4] Kahane, R., Hodgkin, T., Jaenicke, H., Hoogendoorn, C., Hermann, M., Keatinge, J.D.H., Hughes, J.A., Padulosi, S. and Looney, N. (2013) Agrobiodiversity for Food Security, Health and Income. Agronomy for Sustainable Development, 33, 671-6937. https://doi.org/10.1007/s13593-013-0147-8 
[5] Biesalski Hans, K.A. and Tinz, J. (2018) Micronutrients in the Lifecycle: Requirements and Sufficient Supply. Food and Nutrition Sciences, 11, 1-1. https://doi.org/10.1016/j.nfs.2018.03.001

[6] Finco, F.D.B.A., Kloss, L. and Lutz, G. (2016) Bacaba (Oenocarpus bacaba) Phenolic Extract Induces Apoptosis in the MCF-7 Breast Cancer Cell Line via the Mitonchondria-Dependent Pathway. Food and Nutrition Sciences, 5, 5-15. https://doi.org/10.1016/j.nfs.2016.11.001

[7] Touré, M., Stessens, J., Mayao, A.G. and Zohouri, G.P. (2003) Variation saisonnière de l'offre de l'offre et des prix de l'Igname en côte d'ivoire. Agronomie Africaine, 4, 69-82.

[8] Ayessou, N.C., Guèye, M., Dioh, E., Konteye, M., Cissé, M. and Dornier, M. (2009) Composition nutritive et apport énergétique du fruit de Maerua pseudopetalosa (Gil et Gil-Ben) DeWolf (Capparidaceae), aliment de soudure au Sénégal. Fruits, 64, 147-156. https://doi.org/10.1051/fruits/2009010

[9] Ndiaye, B., Ayessou, N.C., Cisse, O. Ibn Kh., Balde, S., Cisse, M., Diop, C.M. and Sakho, M. (2018) Potentialités technologiques par l'évaluation biochimique de la farine des tubercules du souchet Cyperus esculentus L. Afrique Science, 14, 209-214.

[10] Selvakumari, E., Shantha, A.C., Sreenath, K. and Purushoth, P.T. (2016) Phytochemistry and Pharmacology of the Genus Nymphaea. Academia and Industrial Research (JAIR), 5, 2278-5213.

[11] Kabran, G.R., Akhanovna, J., Bekro, M., Pira, J.L., Bekro, Y.A., Sommerer, N., Verbaere, A. and Meudec, E. (2014) Identification de composés phénoliques extraits de deux plantes de la pharmacopée ivoirienne .Soc. Ouest-Afr. Chim, 38, 57-63.

[12] Kameni, M.P., Dzeufiet, D.P.D., Bilanda, D.C., Mballa, M.F., Mengue, N.Y.S., Tchoupou, T.H., Ouafo, A.C., Ngoungoure, M.C., Dimo, T. and Kamtchouing, P. (2019) Nymphaea lotus Linn. (Nymphaeaceae) Alleviates Sexual Disability in L-NAME Hypertensive Male Rats. Journal of Hindawi Evidence-Based Complementary and Alternative Medicine, 2019, Article ID: 8619283. https://doi.org/10.1155/2019/8619283

[13] Jayaweera, D.M.A. (1982) Medicinal Plants Used in Ceylon. The National Science Foundation, Colombo, 50-55.

[14] Blench, R. (2016) Dagomba Plant Names. United Kingdom, Cambridge.

[15] Konda, K. M., Kabakura, M., B., Mbembe, Y’ok. Itufa, Mahuku, K., Mafuta, M., Mpoyi, K., Ndemankeni, I., Kadima, K., Kelela, B., Ngiuvu, V., Bongombola, M., Dumu, L. and Latham, P. (2012) Plantes médicinales de traditions Province de l'Equateur R.D. Congo, Kinshasa. Institut de Recherche en Sciences de la Santé (I.R.S.S.) in Kinshasa, 419 p.

[16] Gueye, F.K., Mbaye, M.S., Dieng, B., Ndour, S., Gueye, M. F., Gaye, A. and Noba, K. (2019) Connaissances endogènes des espèces du genre Nymphaea dans le delta et la basse vallée du fleuve Sénégal. International journal of Current Research, 11, 9130-9134.

[17] Afnor (1982) Produits dérivés des fruits et légumes, jus de fruits. Éd. Afnor, Paris, France.

[18] Greenfield, H., Southgate, D.A.T, (1992) Food Composition Data and Food Composition Data Bases. In: Food Composition, Data, Springer, Boston, MA. https://doi.org/10.1007/978-1-4615-3544-7

[19] Betti, J.L. and Mebere Yemefa, S.R. (2011) Contribution à la connaissance des produits forestiers non ligneux du parc national de Kalamaloué, Extrême-Nord Cameroun: les plantes alimentaires. International Journal of Biological and Chemical Sciences, 5, 291-303. https://doi.org/10.4314/ijbcs.v5i1.68105 
[20] Marc, F., Davin, A., Deglène-Benbrahim, L., Ferrand, C., Baccaunaud, M. and Fritsch, P. (2004) Méthodes d'évaluation du potentiel antioxydant dans les aliments. Studies of Several Analytical Methods for Antioxidant Potential Evaluation in Food. Journal of méDecine Sciences, 20, 453-463. https://doi.org/10.1051/medsci/2004204458

[21] Tonon, R.V., Brabet, C. and Hubinger, M.D. (2008) Influence of Process Conditions on the Physicochemical Properties of Açai (Euterpe oleraceae Mart.) Powder Produced by Spray Drying. Journal of Food Engineering, 88, 411-418. https://doi.org/10.1016/j.jfoodeng.2008.02.029

[22] Kingwatee,N., Apichartsrangkoon, A., Worametrachanon, P.C., Techarung, S. and Pankasemsuk, J.T. (2015) Spray Drying Lactobacillus Casei 01 in Lychee Juice Varied Carrier Materials. LWT Food Science and Technology, 62, 847-853. https://doi.org/10.1016/j.lwt.2014.12.007

[23] Food and Agriculture Organisation (2014) Systèmes Appropriés de Stockage des Semences et des Grains pour les Agriculteurs à Petite Échelle: Pratiques clés pour les praticiens de la RRC. FAO.

[24] Mohammed, H.A., Uka, U.N. and Yauri, Y.A.B (2013) Evaluation of Nutritional Composition of Water Lily (Nymphaea lotus Linn.) from Tatabu Flood Plain, North-Central, Nigeria. Journal of Fisheries and Aquatic Science, 8, 261-264. https://doi.org/10.3923/jfas.2013.261.264

[25] Wasagu, R.S.U., Lawal, M., Galadima, L.G. and Aliero, A.A. (2015) Nutritional Composition, Antinutritional Factors and Elemental Analysis of Nymphaea lotus (Water Lily). Journal of pure and Applied Sciences, 8, 1-5. https://doi.org/10.4314/bajopas.v8i1.1

[26] Ferrari, C.C., Germer, S.P.M., Alvim, I.D., Vissotto, F.Z. and Jaguirre, M. (2012) Influence of Carrier Agents on the Physicochemical Properties of Black Berry Powder Produced by Spray Drying. International Journal of Food Science \& Technology, 47, 1237-1245. https://doi.org/10.1111/j.1365-2621.2012.02964.x

[27] Deffan, K.P., Akanvou, L., Akanvou, R., Nemlin, G.J. and et Kouamé, P.L. (2015) Évaluation morphologique et nutritionnelle de variétés locales et améliorées de maïs (zea mays 1.) Produites en Côte d'Ivoire. Afrique Science, 11, 181-196.

[28] Musa, A., Birnin-Yauri, U.A., Muhammad, C. and Umar, A. (2012) Proximate Composition and Mineral Analysis of Nymphaea lotus Seeds. African Journal of Food Science and Technology, 3, 2141-5455.

[29] Toulsoumdé, L., Ouattara, S., Bationo, F., Parkouda, C., Dao, A., Bassole, I.H.N. and Diawara, B. (2015) Qualité des grains et aptitude à la transformation: Cas des variétés de Sorghum bicolor, Pennisetum glaucum et Zea mays en usage en Afrique de l'Ouest. International Journal of Biological and Chemical Sciences, 9, 2819-2832. https://doi.org/10.4314/ijbcs.v9i6.23

[30] Ballogo, V.Y., Soumanou., M.M., Toukourou, F. and Hounhouigan, J.D. (2013) Structure and Nutritional Composition of Fonio (Digitaria exilis) Grains: A Review International Research. Journal of Biological Sciences, 2, 73-79.

[31] Rémond, D. and Walrand, S. (2018) Les graines de légumineuses: caractéristiques nutritionnelles et effets sur la santé. Innovations Agronomique, 60, 133-144.

[32] Gordon, M.N. (2000) Comtemporay Nutrition, Issues and Insights. 4th Edition, Mc-Graw Hill, New York, 102-256.

[33] USDA (2009) National Nutrient Database for Standard Reference. Release 22: Grain Nutrition Comparison.

http://www.einkorn.com/wp-content/uploads/2009/12/Grain-Nutrition-Compariso 
$\underline{\text { n-Matrix.pdf }}$

[34] Souci, S.W., Fachmann, W. and Kraut, H. (2008) Food Composition and Nutrition Tables.7th Edition, Med Pharm, Stuttgart, Germany, 743-1238.

[35] Ascherio, A., Rimm, E.B., Giovannucci, E.L., Colditz, G.A., Rosner, B., Willett, W.C., Sacks, F. and Stampfer, M.J. (1992) A Prospective Study of Nutritional Factors and Hypertension among U.S. Men. Circulation, 86, 1475-1484.

https://doi.org/10.1161/01.CIR.86.5.1475 